\title{
Osman Hamdi Bey and the Dawn of the Ottoman Museum: a Bourdieusian Approach
}

\author{
Lorenzo Posocco \\ University College Dublin (UCD), John Henry Newman Building, University College Dublin, Stillorgan Rd, \\ Belfield, Dublin 4, Ireland
}

*Corresponding Author: Lorenzo Posocco, University College Dublin (UCD), John Henry Newman Building, University College Dublin, Stillorgan Rd, Belfield, Dublin 4, Ireland

\begin{abstract}
This article focuses on the dawn of the Ottoman museum, which is investigated through a politicalsociological theoretical framework based on the field theory of Pierre Bourdieu. The Bourdieusian framework is integrated with historical sources that helped to make sense of the museum, not just as a cultural institution, but also as a field: a social space structured according to specific laws of functioning. By exploring the life of Osman Hamdi Bey, officially recognized as the father of Ottoman archaeology and museology, I will argue that the Ottoman museum and the museum field were subject to dualities of elitism and nationalism. Respectively, these came in the form of political and economic domination of the Ottoman ruling classes, and the cultural domination of Western Europe, wherein the canons pertaining to the archaeological and museum world in the nineteenth century were established.
\end{abstract}

Keywords: Museum; Ottomanism; Nationalism; Osman Hamdi; Ottoman Museum; Bourdieu

\section{INTRODUCTION}

The great obsession of the nineteenth century was, as we know, history: with its themes of development and of suspension, of crisis, and cycle, themes of the ever-accumulating past, with its great preponderance of dead men ${ }^{l}$

Foucault's quotation above brings us into the very heart of this study on the Ottoman museum. The historical obsession that Foucault links to the $19^{\text {th }}$ century took various forms, among them the museum institution. There is overwhelming evidence for the notion that in the late 18th century, and especially in the 19th century, the amount of museums increased exponentially around the world. ${ }^{2}$ While the number of museums worldwide was growing, another important phenomenon occurred and it is the birth of the modern nation-state. In fact, these two phenomena, the birth and proliferation of the museum and nation-states, are inextricably linked. ${ }^{3}$

As Macdonald put it, one of the key moments of the museum was the French Revolution, commonly seen as the passage from the ancient regime to modernity: the replacement of the pouvoir du roi (the power of the king) with the pouvoir du pouple (the power of the people). Interestingly, the Royal Gallery of the French king was transformed into a museum - the Louvre - open to the public, with royal insignias being substituted with republican ones. The goal was to culture the public, bring high culture to the masses; make the power of the people visible, and to constitute a nation.

1 Foucault, M. (1984) “Des Espace Autres”, in Architecture, Mouvement, Continuité, no. 5 (October 1984): 46-49 http://web.mit.edu/allanmc/www/foucault1.pdf

2 Bennett, T. (1995) The Birth of the Museum. History, Theory, Politics. Routledge. London and New York.

3 Macdonald, S. J.(2003) "Museums, national, postnational and transcultural identities", Museum and Society, 1 (1) 1-16 (2003); Bennett, T. (1995) “The Birth of the Museum, History, Theory, Politics”, Routledge: London and New York (1995); Hooper-Greenhill, E. (1992) "Museums and the Shaping of Knowledge, Routledge London and New York (1992). 
It wasn't long before this model was exported throughout Europe and the rest of the globe, ${ }^{4}$ and it wasn't much longer before (in 1869) the museum reached the Ottoman Empire. ${ }^{5}$ At this time the Ottoman Empire was an aggregate of nations ruled over by a Sultan who also carried the title of Caliph, being successor to the Prophet Muhammad and leader of the entire Muslim community. After centuries of domination, around the time when the Ottoman museum was established, the empire was in decline. European powers had catched up in terms of technology, especially military technology, and became a real threat to the unity of the Ottoman Empire. The Ottoman economy was already under the influence of the West, and the Pax Ottomana was menaced by nationalisms within the empire's borders. Most European states regarded the Ottoman Empire in the same way as Tsar Nicholas I of Russia described it: 'a man who has fallen into a state of decrepitude'.

Once the greatest power in the Middle East and the Mediterranean, the Ottoman Empire struggled to modernize itself; in the first half of the 19th century it started a long period of reforms which are referred to in historical terms as the Tanzimat. ${ }^{7}$ The point of reference for the reforms was Europe, and they involved the import of Western-style institutions, among which was the museum. However, one of the main arguments of this study is that although eminent European museums -such as the Louvre and the British Museum- were sources of inspiration, the Ottoman museum was not a mere copy of them. Certainly, unlike in France, the Ottoman museum did not develop during the turmoil of an armed revolution that marked a passage towards a society in which citizens were equal and equally free from tyrants. The primary aim of this museum was not to enlighten the public. It was certainly not for this reason that the Ottomans were convinced to import the museum institution, create schools to instruct museum personnel, and enact specific regulations which shaped what I will define as the "museum field".

In the eyes of the Ottoman governors, the museum was instead just one piece of the puzzle required to reach the model of modernity epitomized by the West. The new imperative was to import Western institutions. Nationalism, another piece of the same puzzle, also played an important role in the Ottoman museum. The Imperial Museum was, for all intents and purposes, a national museum especially in its 1891 version on which I focus- in the sense that the artefacts, history, myths, and traditions on display within it were meant to exhibit something that had never actually existed: an Ottoman nation as the conglomeration of numerous ethnic groups living within the Ottoman borders. ${ }^{8}$ In the minds of the museum makers, these ethnic groups were meant to share a common past, present, and future, and a specific territory within the Ottoman state, which ruled over them by means of symbolic and physical violence. In particular, the Ottoman Empire was attempting to quell separatist forces within its territory as they were a threat to its status as the biggest power in the Mediterranean. ${ }^{9}$ Given these issues, the Ottoman museum served the goals of the Ottoman administrators: it exhibited the Ottomans as a nation, united beyond ethnic identities and loyal to the Ottoman state; and it rooted Ottoman history in the Roman and Greek civilizations. The museum therefore served two important functions: it solved (on paper) the problem of national unity, and it created a symbolic bridge with the Europeans, amongst whom the Ottomans attempted desperately to find allies. ${ }^{10}$

4 Duncan, C. (2003), "Civilizing Rituals: Inside Public Art Museums (Re Visions: Critical Studies in the History and Theory of Art)", Routledge, Routledge London and New York, 1995: 32, in S. J. Macdonald, "Museums, national, postnational and transcultural identities", Museum and Society, 1 (1), 1-16.

5 Shaw, Wendy M. K. (2011) "National Museums in the Republic of Turkey: Palimpsests within a Centralized State, in Building National Museums in Europe 1750-2010", Conference proceedings from EuNaMus, European National Museums: Identity Politics, the Uses of the Past and the European Citizen, Bologna 2830 April 2011. Peter Aronsson \& Gabriella Elgenius (eds) EuNaMus Report No 1. Published by Linköping University Electronic Press: http://www.ep.liu.se/ecp_home/index.en.aspx?issue=064

6 De Bellaigue, C. (2001) "Turkey's Hidden Past”, The New York Review of Books, 48:4, 2001-03-08. http://www.nybooks.com/articles/2001/03/08/turkeys-hidden-past/\#fnr1

7 Quataert, D. (2000) “The Ottoman Empire, 1700-1922. New Approaches to European History”, Cambridge University Press, Cambridge (2000).

8 Shaw, Wendy M.K. (2014) "National Museums in the Republic of Turkey: Palimpsests within a Centralized State".

9 Feroz Ahmad, The Young Turks and the Ottoman Nationalities, The University of Utah Press, Salt Lake City, (2014).

10 Faroqhi, S. (2007) "Subjects of the Sultan: Culture and Daily Life in the Ottoman Empire", I.B. Tauris. London and New York (2007). 
A series of social agents took part in the creation of this museum. Among them was Osman Hamdi Bey, arguably the most renowned Ottoman intellectual of his time. The case study of Hamdi is crucial for understanding the birth and development of the Ottoman museum. By investigating the life of Hamdi -an archaeologist, a historian, a painter, a bureaucrat, the director and curator of the first Ottoman museum and the figure who contributed most to its creation- I will argue that the Ottoman museum was not a museum of, but rather for, the Ottoman nation by the Ottoman elites. Hamdi belonged to these elites and supported Ottomanism: the national ideology that advocated for a strong Ottoman State at the head of a united Ottoman nation. ${ }^{11}$ The museum that he designed and curated mirrored this national ideal.

By discussing the available historical data I will argue that Hamdi was "a man between two worlds" as the historian Edhem Eldem ${ }^{12}$ has described him, but was also, and above all, a man of his time. He lived in a historical period of growing nationalisms whose influencing forces moulded and influenced his national habitus, thereby affecting the creation of the Ottoman museum as a national museum.

In addition, Hamdi Bey functions here as the lens through which, looking at the museum as an institution born in conjunction with the birth of an Ottoman museum field, we can see that it is structured according to specific laws that dictated the organizing principle of the archaeological and museum world in 19th century. Finally, by applying a Bourdieusian view to the available historical sources, I will point out that the Ottoman museum developed through the combination of individual agency and structure. The genius of Osman Hamdi and other museum makers made the museum a distinctively Ottoman creation, but it will become clear that they were inevitably influenced by the society in which they lived. Thus, I will attempt to show that the Ottoman Museum was the result of individual agency and structure: two factors that, like a hermeneutic circle, never cease to influence each other.

\section{MUSEUM FIELD: THE EXAMPLE OF OSMAN HAMdi BEY}

The first distinction to be drawn is the distinction between the museum and the museum field. A field is a conceptual tool, not a physical space. Field analysis assists the investigation of power relations, hierarchies, and struggles for the financial, political, or personal profits at stake in the particular field; whereas the museum is, obviously, a physical space housing artefacts etc. By adapting Bourdieu's definition of field, ${ }^{13}$ to the study of the Ottoman museum, I define the museum field as a network or configuration of relations between types of capital possessed by social agents or institutions that pertain to the world of the museum. The museum field is characterized (mainly, but not only) by cultural capital, and includes professions ranging from: museum directors; curators specialized in arts, history, science, archaeology, photography, etc.; restorers specialized in painting, sculpting, etc.; and artists such as painters, sculptors, video artists etc. Social agents are distributed in the museum field according to the type and volume of capital they possess. Their position (dominant, subordinate, homologous) within the field depends on their capital.

To explain how capital reflects one's position in the museum field, I provide the example of Osman Hamdi Bey. Archaeologist, historian, painter, bureaucrat, and director of the first Ottoman museum, Hamdi is perhaps the most renowned Ottoman intellectual and, as I will argue in the following sections, the one who contributed most to the development of the Ottoman museum and the museum field.

Hamdi was born in 1842 in a family of the Ottoman ruling class. His father, Edhem Pasha, occupied several ministerial and ambassadorial positions and was appointed Grand Vizier during the reign of Abdülhamid II. As a Grand Vizier, Hamdi's father worked as adviser to the Sultan and served in a number of important roles, such as minister of foreign affairs. Being the son of Edhem Pasha endowed Hamdi with a large amount of social capital, which included contacts from the highest

11 Cleveland W. and Bunton, M (2013) “A History of the Modern Middle East”, Westview Press, Boulder Colorado.

12 Eldem, E. (2004) “An Ottoman Archaeologist Caught Between Two Worlds: Osman Hamdi Bey (18421910)", in David Shankland (ed.), "Archaeology, Anthropology and Heritage in the Balkans and Anatolia: The Life and Times of F. W. Hasluck, 1878-1920”, Istanbul, Isis Press (2004).

13 Bourdieu, P. (1990) "Social space and symbolic power”, in Pierre Bourdieu, "In Other Words: Essay

Towards a Reflexive Sociology”, Cambridge: Polity Press (1990): 123-139. 
spheres of Ottoman and international society. These contacts played a crucial role, as I will point out, in his personal and professional life.

Hamdi's cultural capital was, like his social capital, above the general standards for his time. In fact, his father Edhem Pasha had sufficient economic capital to grant him the best education. Like his father before him, Hamdi studied and travelled in Europe, eventually settling in Paris where he first attended law school. The cultural life of Paris, the cradle of art in 19th century Europe, had a huge impact on Hamdi's development at this age. After nine years, he left to study painting at the atelier of two renowned orientalist painters: Boulanger and Gérôme. Later on, he was introduced to archaeology by one of the most active archaeologists of his time, Theodore Reinach, with whom he worked in 1887 on the excavation of the royal necropolis of Sidon in Lebanon. ${ }^{14}$

Hamdi's social capital granted him the support of the ruling classes and his cultural capital legitimated his position within them. In 1870, after returning to Istanbul, he was appointed to the service of Midhat Pasha, governor of Iraq, which at the time was an Ottoman province. In 1871 he was appointed deputy chief of protocol and served as the Ottoman commissary for the World Exhibition of 1873. In 1875 he was appointed the head of the Bureau of Foreigners at the Ministry of Foreign Affairs. 1881 saw him being appointed director of the Imperial Museum, and in 1882 he became director of the first Academy of Fine Arts in the Ottoman Empire (today's Mimar Sinan University). ${ }^{15}$ We lack information about the exact financial situation of Hamdi (his economic capital), but everything suggests that he enjoyed the wealth typical of a high level bureaucrat at that time.

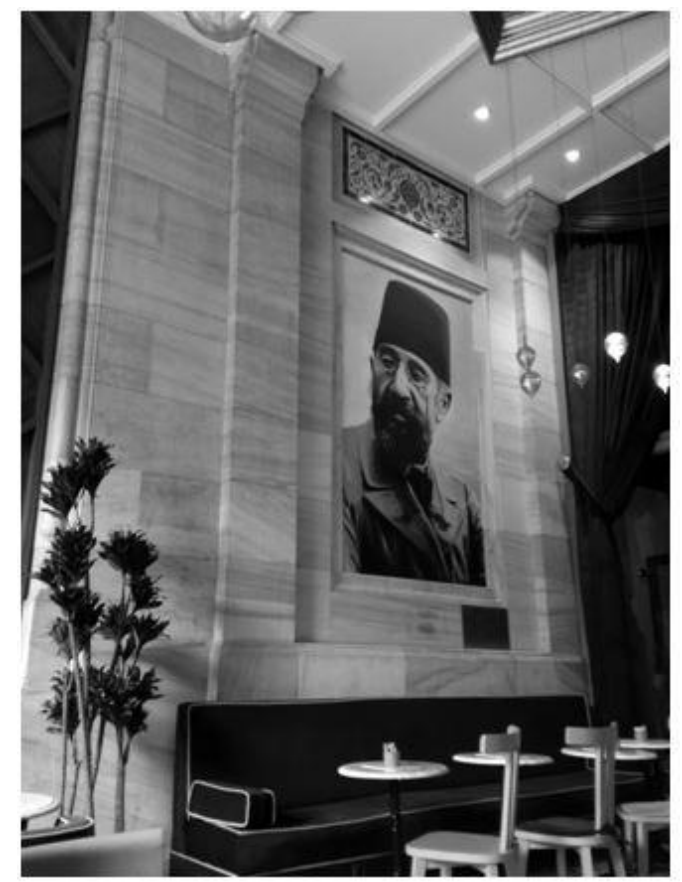

(Image 1. I took this picture of Hamdi in an ordinary café in Istanbul. The plaque reproduced the common belief of Hamdi as an extraordinary talent and master in the field of archaeology, history, museology, arts, etc.)

Hamdi's symbolic capital, or power of authority, increased considerably after his excavation of the Necropolis of Sidon (1887), where the alleged Sarcophagus of Alexander the Great was found. Hamdi's increased symbolic capital, not only as the museum director of the Imperial Museum but also as an archaeologist, is reflected by his correspondence with the most illustrious names in Western archaeology. Theodor Mommsen, Otto Puchstein, Georges Perrot, Friedrich Sarre and other eminent archaeologists of the time saluted him by using expressions such as 'Excellence,' 'Excellence and dear honoured colleague,' 'My dear Bey,' and 'My dear friend'. ${ }^{16}$

14 Eldem, E. "An Ottoman Archaeologist Caught Between Two Worlds: Osman Hamdi Bey (1842-1910)".

15 Eldem, E. (2010) “An Ottoman Traveller to the Orient: Osman Hamdi Bey”, University of Washington Press, Washington (2010).

16 Henri Metzger, "La correspondance passive d'Osman Hamdi bey", Diffusion de Boccard, Paris (1990). 
This archaeological expertise endowed Hamdi with a large capital of authority which ensured his success. As the director of the Imperial Museum, and the person who exercised strict control over the antiquities within the immense regions of the empire, Hamdi made himself indispensable "through services rendered to his colleagues abroad". ${ }^{17}$ Indeed, most of the correspondence between him and his European colleagues contain references to the favours that he granted to them. Dealing with European (in particular French) institutions was an immense source of profit for Hamdi, e.g. in exchange for his authorization to export certain artefacts to France, the French National Museum purchased one of his paintings for a large sum of money, and he was later appointed Foreign Corresponding Member of the Institut de France. ${ }^{18}$

It is clear that Hamdi benefited of a high position in the fields of Ottoman museology and archaeology, and in Ottoman society as a whole. To make this concept clearer, I have designed the following graphic.

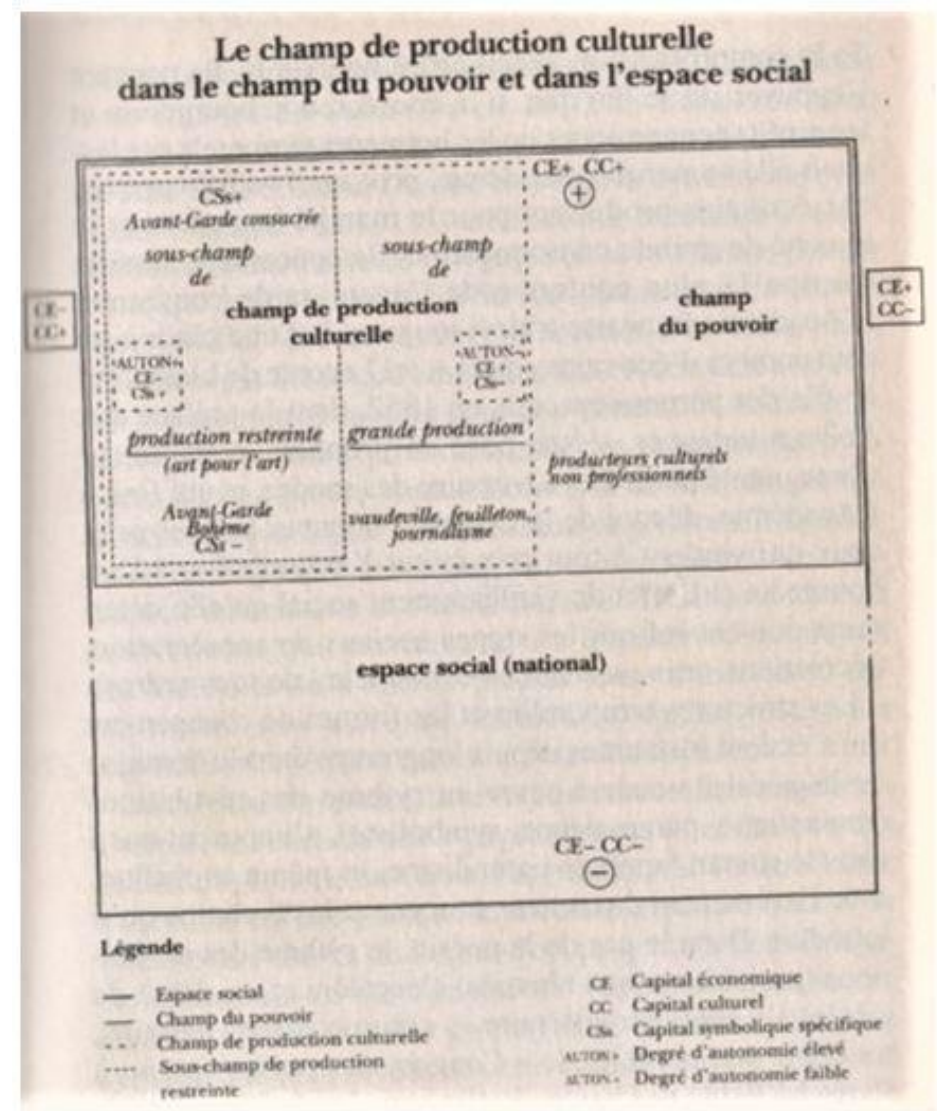

(Image 2. Field of cultural production. Bourdieu, P. (1993) Les Règles de l'art. Essais. Paris, p. 205)

Fig. 2 represents the field of power, which is the Bourdieusian conceptualization of the cultural production. People positioned on the upper-left side are characterized by a high concentration of cultural capital (CC+) and a relatively low economic capital (EC-) in comparison to the professions on the right side, which are charachterized by economic power, e.g. magnates of industry, businessmen, etc. Bourdieu includes both upper-left and upper-right corners in the field of power, a field that, to put it with Charles W. Mills (2000 [1956]), identify what he calls the "higher circles", the dominant classes in society.Instead, the lower part of the graphic is characterized by lower levels of economic and cultural capital, and identifies the larger national field: the people. The upperleft corner represents the position that Hamdi held in Ottoman society. He was an artistic producer, a professor, a bureaucrat, and a cultural intermediary. Bourdieu referred to these people as the "dominated fraction of the dominant class". ${ }^{19} \mathrm{He}$ demonstrated that the field of politics and the field

17 Eldem, “An Ottoman Archaeologist Caught Between Two Worlds: Osman Hamdi Bey (1842-1910)", 132.

18 Ibid, 144.

19 Ibid., 15. 
of economy (both on the right part of the graphic) had power over them. Vis-à-vis this data, some questions arise naturally: did the relations of power between politics and culture during the time of the Ottomans reflect this condition? Was the cultural field subject to the political field, and in what way?

\section{The OTTOMAN MUSEUM FIELD}

The cultural field, although it is within the field of power, possesses only a relative autonomy; in particular it is judicially, economically, and politically dominated. The graphic in Fig. 3 renders this result visually. As it resembles a similar graphic sketched by Bourdieu, I will use Bourdieu's words to explain it: "[in Fig. 3], the literary and artistic field (3) is contained within the field power (2) while possessing a relative autonomy with respect to it as regards its economic and political principles of hierarchization. It occupies a dominated position (at the negative pole) in this field, which is itself situated at the dominant pole of the field of class relations (1)". ${ }^{20}$

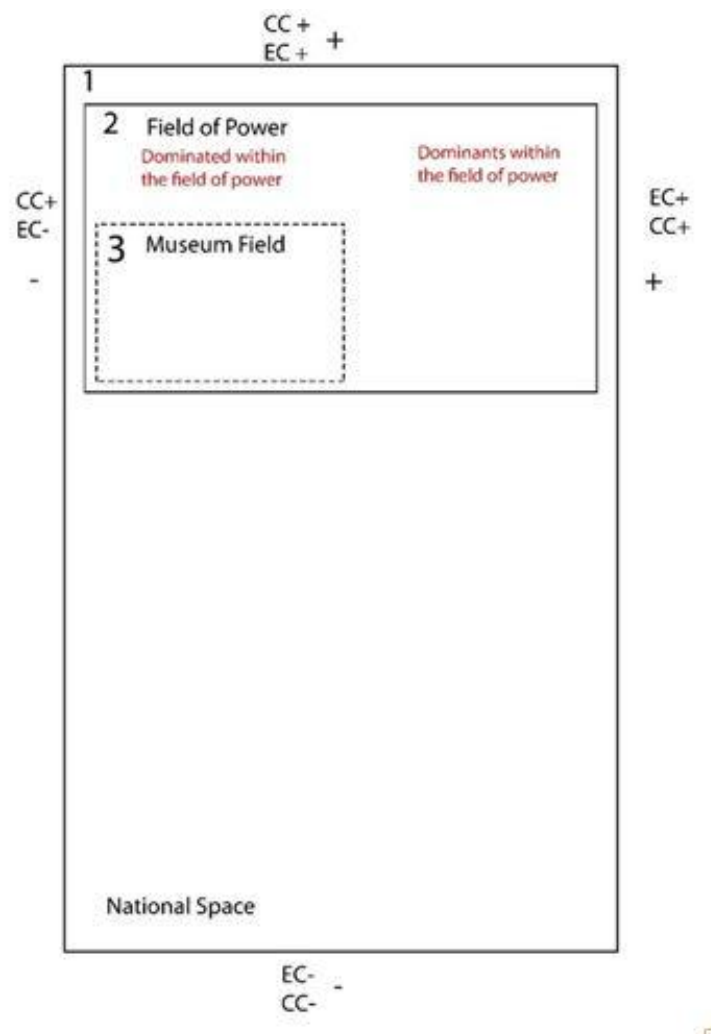

(Image 3. The field of cultural production. From Bourdieu, P. 1993 The Field of Cultural Production. Columbia University Press. United States of America. Pp. 37)

I have added a fourth square to Fig.3 identifying the museum field. With regard to the Ottoman museum field, its limited degree of autonomy started with the introduction of specific regulations that addressed the museum and archaeological spheres. Through the law, implemented and enforced by the police, the state affirmed its dominance over the museum field. To illustrate, I note articles of law such as Art. 3 of the Antiquity Law of 1884:

Any kind of ancient artefact or relic discovered in the lands of the Ottoman, even those which will appear during excavations and in seas and lakes and rivers will belong entirely to the state $^{21}$

And Art. 7:

Nobody can perform excavations in the lands of the Ottomans without the official permit which matches the decisions and conditions indicated in this regulation ${ }^{22}$

20 Bourdieu, P. (1993) The field of cultural production. Columbia University Press. United States of America. Pp. 37-38.

21 Regulation on Antiquities, 20/02/1884.

22 Ibid. 
Not only did the government have a monopoly over the antiquities above or below ground, but it also exercised domination over the museum itself. This domination was twofold: political and economic. Articles 3, 4, 5, 10, and 14 of the 1889 Regulation on the Affairs of the Museum define how it was only the government who could appoint museum personnel, whether museum directors, deputy directors, assistants, etc. Museum directors - like Osman Hamdi - had some autonomy, which included the appointment of guardians, gardeners, and doorkeepers (Art. 7). The guardians which were appointed by the Museum Directorate were supervised themselves under Article 17. Law even decided at what times the museum opened or closed (Art. 15).

If the museum was in need of an officer carrying higher responsibilities, the museum director was obliged to prepare an official request to the government. The Ministry of Education would then hire and appoint the officer (Art. 11). In brief, the politicians exercised a double domination over the museum field. They decided who was to be appointed and where, and the amount of money that the appointee received. Moreover, by means of law, the administrators imposed duties, rights, punishments and the terms of conduct of the appointee. These evidences corroborate the incorporation of the Ottoman museum field in a dominated position in the field of power.

The heteronomous domination of the museum field wasn't only a matter of law, but also one of class position. Social agents that occupied positions within the museum field - such as archaeologists, museum directors, and other specialised officers - came, like Osman Hamdi (see previous section), from the higher classes. ${ }^{23}$

We must consider that, in the 19th century, the Ottoman Empire was based on an agrarian economy, and its governors were struggling to modernize it. ${ }^{24}$ As part of the cultural field, the museum field was defined by a higher cultural capital (especially specific knowledge regarding antiquities). With this in mind it is not surprising that in 1883, when traveling through Anatolia and the Kurdish regions of the empire, Hamdi Bey looked down on the people he met. ${ }^{25}$ To him, the people of these regions seemed backward and had nothing in common with his sophisticated museum in Istanbul or the high-cultured Parisian lifestyle he had previously experienced. However, although Hamdi occupied a position of power within the museum field, the political administrators, sultans, viziers, and the higher spheres of bureaucrats were above him, and even above the law. ${ }^{26}$

\section{LAWS, SCHOOL PERSONNEL, AND BUREAUCRACY: ELEMENTS NECESSARY TO THE BIRTH OF THE MUSEUM FIELD}

When Hamdi was appointed director of the Imperial Museum in 1881, the museum field only existed in a proto-form. In the Ottoman Empire, few social agents had the cultural capital required to fulfil the position as a curator or museum director; those who did had attended higher education and occupied high positions in society. One of the elements that hindered the development of the museum field in the Ottoman Empire was an inadequate educational system. In Istanbul, the capital of the empire, there were no schools, universities, or academies dedicated to the arts. To fill this gap, the establishment of an Antiquity School was proposed in 1875, but the project failed due to both a lack of funding and students. ${ }^{27}$ The first academy of arts, today's Mimar Sinan University, was founded by Hamdi in 1882. In brief, the Ottoman Empire lacked the cultural tools that in Europe had facilitated a greater development of the museum. However, a bureaucracy pertaining to the world of antiquities did exist in a proto-museum field.

This bureaucracy developed in tandem with the enforcement of a series of reforms and regulations, such as: the Antiquity Law of 1869, 1874, and 1884; the 1889 law on Regulation of the Internal

Affairs of the Museum; and the creation of the Museum Directorate in 1869. Bourdieu has often referred, especially in his lesser known political sociology works, to the judicial power of the

23 Eldem, E. (1997) “Istanbul 1903-1918: A Quantitative Analysis of a Bourgeoisie”, Review of Social, Economic, and Administrative Studies, Vol. 11 N. 1 - 2, 53 - 98 (1997).

24 Quataert, "The Ottoman Empire, 1700-1922. New Approaches to European History".

25 Eldem, "An Ottoman Traveller to the Orient: Osman Hamdi Bey".

26 Eldem, "An Ottoman Archaeologist Caught Between Two Worlds: Osman Hamdi Bey (1842-1910)".

27 Shaw, Wendy M. K. (1999) "Possessors and Possessed, Museums, Archaeology, and the Visualization of History in the Late Ottoman Empire”, University of California Press, Berkley and Los Angeles, California. 
bureaucratic state as the means through which it holds on to - both through symbolic and physical violence - the monopoly over a certain territory. ${ }^{28}$ By developing an Ottoman bureaucracy specifically dedicated to the antiquities, the Ottoman state ensured its domination over them.

A series of professional figures were created: public officers to control excavation sites (Law 1884, Art. 21); experts of the Imperial Museum who evaluated the unearthed artefacts and relics (Law 1874, Art. 26; Law 1884, Art. 29); officers who controlled the excavators and registered all the findings into a record book to be returned to the Museum Directorate (Law 1874, Art. 26; Law 1884, Art. 29); and officers from the Zaptiye Nezaret (the highest body responsible for homeland security) whose function was to ensure that license owners acted according to the Ottoman regulations (Law 1874, Art. 9). Furthermore, a number of officers working in the new-born Imperial Museum were needed. Among them: a museum director, a deputy director, one officer for each of the six departments of the Imperial Museum, an accountant, a chief officer, and an officer responsible for photography and restoration. ${ }^{29}$ This small group of professionals must be seen as the first social agents of the Ottoman museum field.

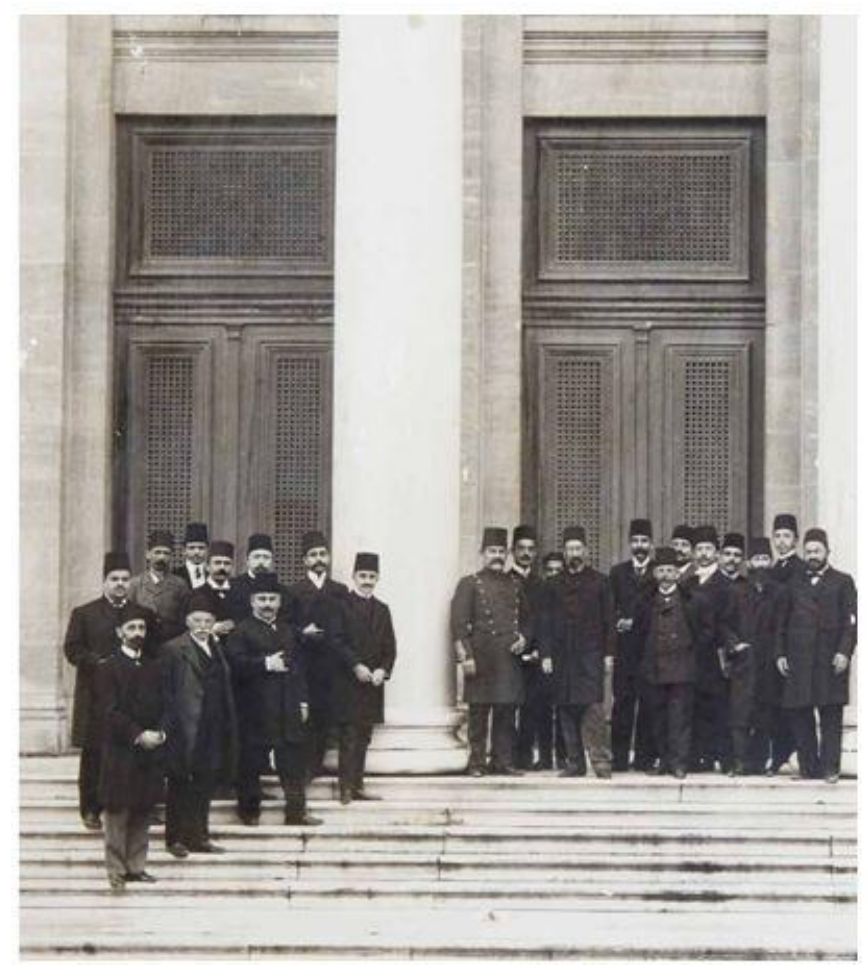

(Image4. Inauguration of the second section of the Imperial Museum 1903: 1. Osman Hamdi Bey, director of the Imperial Museum 2. Osman Hamdi Bey's brother Halil Edhem Bey, deputy director of the Imperial Museum 3. Architect Alexandre Vallauri 4.Osman Hamdi Bey's son-in-law and art historian Vahid Bey 5. Librarian Vassileios Mystakidis Efendi (?) 6. Osman Hamdi Bey's son, archaeologist and architect Edhem Hamdi Bey 7. Imperial Museum commissary Theodoros Makridis Bey [?]. Source Eldem (2012: 9)

\section{EXHIBITING THE OTTOMAN NATION: DYNAMICS OF NATIONALISM AND ELITISM IN THE ARCHI- TECTURE AND THE NARRATIVE OF THE IMPERIAL MUSEUM}

Although at the end of the 19th century the Ottoman museum field was still developing, an Ottoman museum did exist. The Imperial Museum (especially in its version of 1891)was designed by Osman Hamdi and the architect Alexander Vallaury andwas a national museum in the sense that itsexhibit was meant to represent what had never existed: an Ottoman nation as the conglomeration of numerous ethnic groups living, united, within the Ottoman borders. ${ }^{30}$ Museums are always the product of the

28 Bourdieu, P. (2014) "Sur l'état", Seuil, Paris.

29 Regulation on Antiquities, 05/04/1874, Art. 1 - 36.

30 Shaw, "National Museums in the Republic of Turkey: Palimpsests within a Centralized State". 
dominant ideology of their time incarnated in the experts that built them (Posocco, 2021). The Ottoman museum is no exception. Many studies see museums as "tools used by" elites to represent and exhibit the elites' ideal of nation. ${ }^{31}$ This view suggests an instrumental role of the museum while overlooking the role of ideology. All ideologies, therefore also nationalism, provide a set of imaginary relationships of individuals to the real world that are necessary to interact with it (Althusser, 2001). We are always within ideology, and different ideologies are but different representations of our social and imaginary reality (Althusser, 2001: 109). Nationalism as the 'dominant mode of political legitimacy and collective subjectivity in the modern era' (Malešević, 2019: 17) creates an imaginary representation of the self as a national self immersed in a world appearing, naturally, as a world of nations. The case of the Ottoman museum helps to see that an instrument of the elites, the museum is the projection of the dominant ideology of their time.

In the $18^{\text {th }}$ and especially $19^{\text {th }}$ century, nationalism became was turning the world in a world of nationstates. It was worming its way through the intellectuals, the economic and cultural elites such as Hamdi and Vallaury, and it was gradually incorporating other social groups, the middle classes, the bureaucratic organs of the state, army, police, bureaucrats, workers, and so on. Nationalism was becoming structure institutionalized in the state and was developing an extensive organizational capacity while offering a perspective of liberation and collective emancipation that not many ideologies, especially not imperialism, had. These were all elements that increased its ideological penetration.

The creators of the Ottoman museum, especially Hamdi, lived in a changing world where nationalism was becoming the dominant ideology, he espoused it and his museum represented it. Hamdihad been exposed to both European (especially French) and Ottoman nationalism, and developed a national habitus, as Bourdieu and Wacquant ${ }^{32}$ called the dispositions, capacities and propensities which shape one's attachment to the nation, one's national values, national beliefs, national interests, national expectations, and the whole set of lenses through which people perceive the world as a world of nations.

The available literature on Hamdi suggests that he was not a radical nationalist, but we know that in 1869 he left France for the Ottoman Empire and served in Iraq under Midhat Pasha, one of the leading Ottomanists of his time. ${ }^{33}$ The Iraqi experience must have left a mark on Hamdi. In particular, it reinvigorated his feelings for the Ottoman nation and increased his concerns for the Ottomans' future. This is most clear when looking at Hamdi after 1870. He cared more about the Ottoman Empire than he did in his long years in France, he was more worried about the position of the Ottoman Empire in the world stage, and less inclined to seek his Parisian dreams, which just a few years earlier had meant so much to him. ${ }^{34}$ Later, when Hamdi became the director of the Imperial Museum and designed the new building, he projected the Ottomanist ideal of nation into it. In the eyes of Hamdi, the Ottomans were the heirs of ancient civilizations such as the Greek, Roman, Byzantine, and Islamic civilizations. Hamdi's feelings for the Ottoman nation suggested to him that the Ottomans were the result of all the positive influences of these great civilizations, whereas the last centuries of the Ottoman Empire, its defeats, loss of territory, and economic crises, weren't representative of it. ${ }^{35}$ Hamdi saw the period between the 14th and 17th centuries as the golden age of Ottoman history: a time of victories and honours. It is no coincidence that the Imperial Museum mirrored theseviews and exhibited artefacts from the Roman time to the 17 th Century, overlooking more recent history. ${ }^{36}$

Although Ottoman, Hamdi had lived in Europe for some time. He admired the West and yet belonged to the Middle-East, and these two habitus, Western and Middle-Eastern, found their place in the Imperial Museum. By reading Hamdi's letters to his father Edhem Pasha we can make sense of this. ${ }^{37}$

31 Elgenius, G. (2015) "National museums as national symbols: a survey of strategic nation-building and identity politics; nations as symbolic regimes". Routledge. London and New York.

32 Navarro, Z. (2006) "In Search of Cultural Interpretation of Power", IDS Bulletin 37(6): 11-22.

33 Eldem, "An Ottoman Archaeologist Caught Between Two Worlds: Osman Hamdi Bey (1842-1910)"

34 Ibid.

35 Ibid., 125.

36 Eldem, E. (2012) "Making Sense of Osman Hamdi Bey and his paintings", Muqarnas an Annual for the Visual Culture of the Islamic World. Volume 29.

37 Eldem, E. (1991) “Quelques lettres d'Osman Hamdi Bey à son père lors de son séjour en Irak (1869-1870)", Anatolia Moderna - Yeni Anadolu, I/1, p. 115-136. 
Although the West exercised a significant influence over the young Hamdi, his father struggled to raise his son as a Muslim and an Ottoman. These two habitus, which included two sets of -at times contrasting- tendencies, coexisted in Hamdi and were projected in his museum as two sides of the same coin. He collected artefacts that, after being catalogued, analysed, organized, and exhibited, constructed "a meta-narrative of identity rooted in intrinsic links between the empire and Western civilization". 38

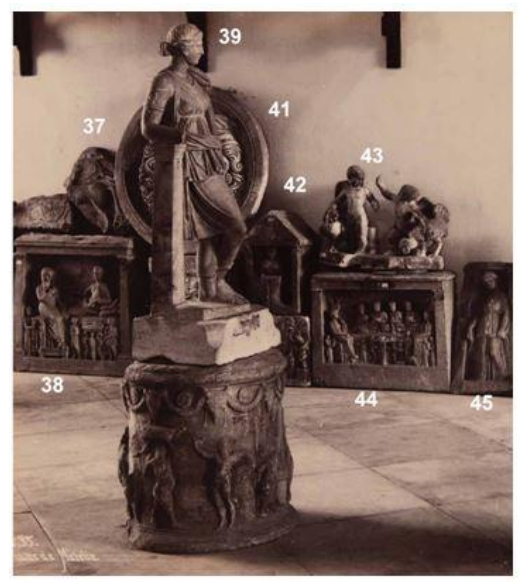

(Image 5. 37 Archaic relief fragment: chariot driver. 525 (32). Cyzicus. Date of acquisition unknown. 38 Funerary banquet. 980 (16). Istanbul, Fatih. 1876. 39 Statuette of Artemis. 533 (121). Lesbos. Acquired ca 1865. 40 Circular altar. 564 (122). Provenance and date of acquisition unknown. 41 Medallion with Medusa's head. 145 (15). Istanbul, Hagia Sophia (?). Acquired before 187042 Archaic stela representing Cybele enthroned. 520 (12). Cyme. Acquired in 1881. 43 Two Eros playing with roosters. $554(57,58)$. Tarsus. Date of acquisition unknown. 44 Funerary banquet. 1020 (11). Cyzicus. Date of acquisition unknown. 45 Funerary stela. 871 (99). Provenance and date of acquisition unknown. 46 Herma of Dionysos. 561 (34). Provenance and date of acquisition unknown. Source: Eldem (2014: 49)

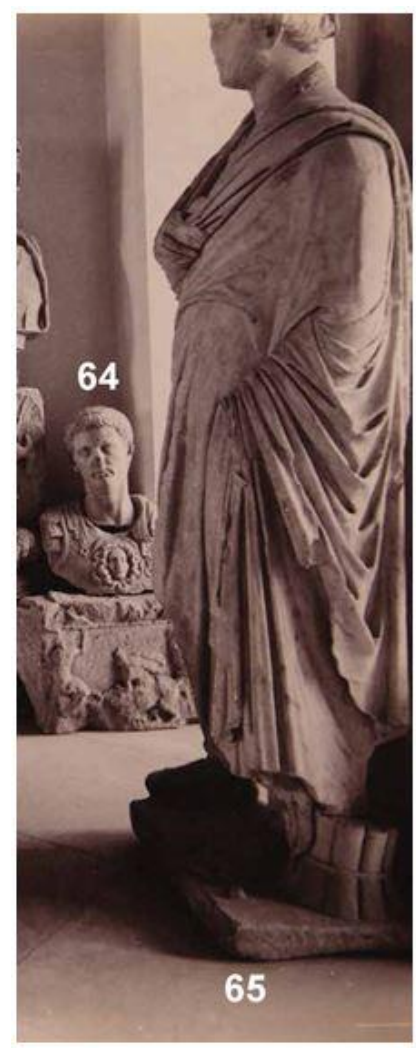

38 Shaw, Wendy M. K. (2007) "Museums and narratives of display from the late Ottoman Empire to the Turkish Republic", in Bozdoğan S. and Necipoğlu G., Muqarnas, "History and Archaeology of the Lands of Rum", Brill, Leiden - Boston: 258. 
(Image 6. 64 Bust of Augustus. 588 (87). Izmit. Acquired in 1880. 65 Statue of a priest of the imperial cult. 582 (103). Cyzicus. Acquired in 1869. Source: Eldem (2014: 9)

These pictures from an old catalogue of the Imperial Museum show Hamdi's structuring of the museum exhibition. Pictures 5 and 6 show the Roman heritage of the Ottomans. Picture 7 shows the relief of a standing genie excavated in Nimrud (today's Turkey) close to a statue of a man from Cyrene (Libya), with a votive stela from Thessaloniki (Greece), near a high relief of Herakles from Troy (Turkey). These territories were located, at the time of Hamdi, within the Ottoman borders. Hamdi's arrangement of the exhibition demonstrates once more his nationalist stance. He saw the Ottoman civilization both as the heir of the Greek and Roman civilization and the latest of these civilisations in terms of lineage.

At the time of Hamdi, social Darwinism was gaining in popularity, and historians believed that a scale of historical and social evolution existed. The Europeans thought of themselves as the last civilization on the path of evolution, but the Ottomans did not stand on the side-lines. With the Imperial Museum, Hamdi made space for them in the circle of the civilized powers. One cannot but glimpse, in this historical taxonomy, the hand of the museum maker. Hamdi's national habitus, his loyalty to the Ottoman state and his intent to redeem the Ottoman nation, play a significant role in the making of the Ottoman Museum. And yet, the museum institution was a European institution that the Ottoman Empire, thanks also to the work of Hamdi, imported from Europe. It was carefully designed respecting the European canon but it served an Ottoman purpose.

The architecture of the Imperial Museum also reflected the taste of the museum makers. In particular, it mirrored the dominant artistic canons imposed by 19th century Europe. Hamdi commissioned the museum's construction project to his acquaintance, Alexander Vallaury, an Ottoman-Levantine who, like him, had studied in Paris at the prestigious École Nationale Supérieure des Beaux-Arts.

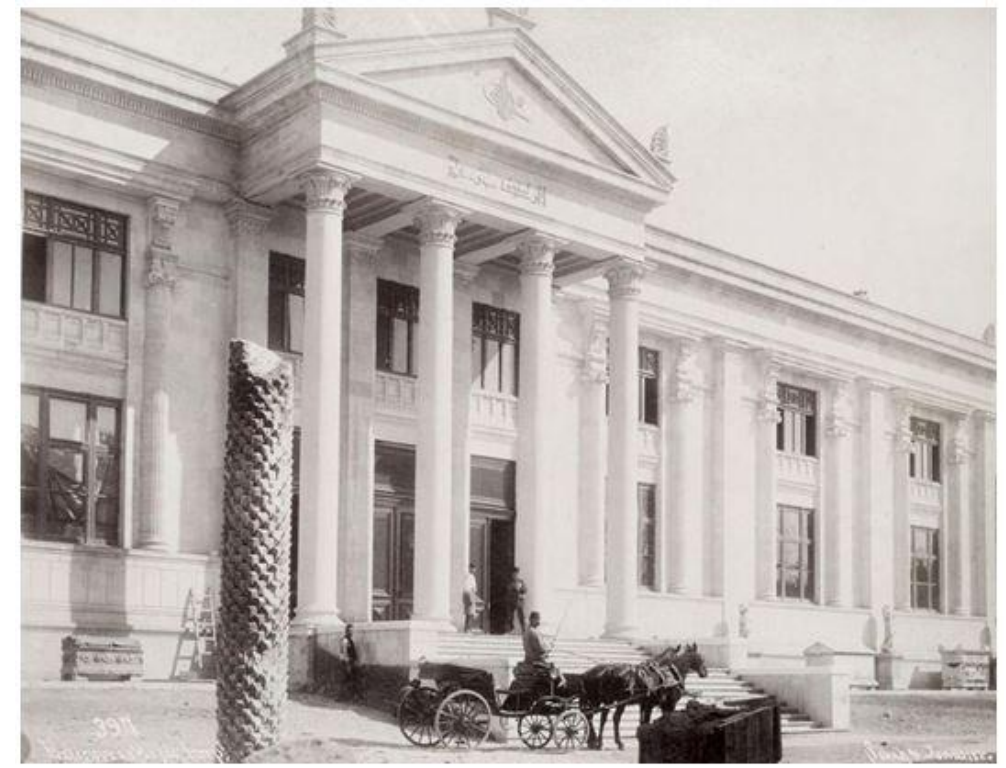

(Image 8. The Imperial Museum in its 1891 version)

The Imperial Museum was designed on the basis of the alleged Sarcophagus of Alexander, which was unearthed during Hamdi's excavations of the necropolis of Sidon in Lebanon. Its architecture illustrated the idea of the Ottomans as being the inheritors of the ancient Greek civilisation. This type of cultural appropriation was commonplace in the Ottoman past. However, in the 19th century things were different. The Greeks had fought for and achieved their independence from the Ottomans, but frictions and resentments still endured. A museum that so openly recalled common roots with the Greeks showed the mark of the symbolic power that European culture exercised over the Ottoman culture. To most Ottomans, European culture (especially art, architecture, and technology) was perceived as the dominant culture, with its aesthetic canons derived from the renaissance, and 'spread with nineteenth-century industrial capitalism to distant continents'. ${ }^{39}$

39 Kaplan, F. (2011) "Making and Remaking National Identities": 152, in Sharon Macdonald (Ed.) "A companion to Museum Studies", Wiley-Blackwell (2012). 
The Ottomans were subject, as much as the Europeans, to the dynamics of Orientalism as disclosed by Edward Said. ${ }^{40}$ The proof of this is that artists and architects like Hamdi and Vallaury went to Europe to study. Hamdi was an orientalist, maybe not in his intent but certainly in style, and his art resembled the art of the French orientalist. ${ }^{41}$ Is it surprising if even the architecture of the Ottoman museum resembled the canons established by Europe? Both Vallaury and Hamdi had lived in Europe for many years, and Vallaury had frequented the French grand écoles where those canons were established. The two students were exposed to them, internalised them, and later mirrored them in what became the first Ottoman museum: the Imperial museum.

\section{Conclusions}

Unlike in France, the Ottoman museum did not develop during the turmoil of an armed revolution that marked the passage from the power of the king to the power of the people. This was never the case in the Ottoman Empire, which was characterized by a strong state and a highly centralized bureaucracy. The Ottoman museum was never a museum for the people, but a state-sponsored institution which mirrored the ideology of the ruling classes and was built to keep pace with the progress of the European powers. The museum was, together with national academies, theatres, schools, orchestras, etc., one of the many cultural institutions imported from the West. Coincidentally, with the advent of the first Ottoman museum a social space developed, which I have called the "museum field". Initially limited to a small group of professionals operating in the world of heritage, the museum field was a social space characterised by social agents who possessed the cultural capital to design and manage the museum. It was characterised by an internal hierarchy which mirrored the variation of capitals possessed by social agents. The more capital, the higher the position in the field; less capital equalled a lower field position.

The Ottoman museum field was embedded within the field of power. Its social agents were the expression of the ruling classes: the dominant fraction of the Ottoman society. Although occupying a dominant position, the museum was subjected to heteronomous principles of organization. That is to say, the organizing principles of the field were dictated (officially in the forms of articles of law or unofficially by personal relations) by the Ottoman administrators that exercised a sort of monopoly over the field. This led to the limited autonomy (or great heteronomy) of the museum. The administrators dictated the appointment of social agents within the museum field, as well as duties and punishments of its social agents. Nonetheless, the latter kept some freedom. Osman Hamdi, father of the Ottoman museum, represents the perfect example of the dominant and yet dominated individual. He was the director of the Imperial Museum and a celebrity in the world of Ottoman archaeology. However; he was appointed by the highest spheres of the state and was therefore dependent on their blessing.

The museum field was born in the same era as the Imperial Museum of Istanbul. By building their first museum, the Ottoman administrators started slowly but resolutely to protect the antiquities above or below the soil of the Ottoman state. For the first time in Ottoman history, antiquities acquired importance under law. Furthermore, vases, bracelets and necklaces started to be labelled as Ottoman vases, bracelets, and necklaces. Behind this taxonomy of antiquities lay the germs of nationalism, which in the 19th century spread quickly from the West to the Ottoman regions. I have underlined that the Ottoman Empire included a conglomerate of nations, but it tried to play the card of nationalism and unite them under the Ottoman flag. Although the project failed, nationalism made its way through the Ottoman administrations and eventually entered the Ottoman museum. I have made the point that although the official denomination of the museum was Imperial Museum (Müze-i Hümayun), it was in fact a national museum insofar that it represented the Ottomans as a conglomeration of ethnic groups united under Ottoman state rule. The Ottoman museum did not completely resemble national museums in the West. It certainly did not exhibit the Ottoman nation as did its French counterpart, the Louvre, which so directly referred to the French and France as a cohesive nation. However, the two museums shared many factors ranging from content display to architecture.

Osman Hamdi, the designer, director, and curator of the museum, is once again an exemplar of the Ottoman museum as a national museum, and the Ottoman counterpart of the European museum.

40 Said, E. (1978) “Orientalism”, Pantheon Books, New York.

41 Eldem, "Making Sense of Osman Hamdi Bey and his paintings". 
Hamdi belonged to the Ottoman ruling class (his father Edhem Pasha was Grand Vizier, the Sultan's advisor, and had served as Minister of Foreign Affairs) and was educated in Paris. He had experienced and internalized values, beliefs, and expectations from two distinct settings: the Ottoman and the European. He was born in Istanbul where he lived until the age of fifteen years, whereupon he moved to Paris to study law. There he remained for eight years, where he was exposed to the European culture and nationalism which inevitably combined with his Ottoman background. This combination of Ottoman and European influences fused into Hamdi's habitus, becoming reflected in the Ottoman museum. The Ottoman museum blended European architecture and content display with the national ideology of its creators: Ottomanism.

I have stated that Hamdi was not a radical nationalist. His museum, however, ended up serving Ottomanism, which was the dominant national ideology of Hamdi's time. I was particularly struck by this detail and I aimed to make sense of it. Hamdi was certainly a man caught between two worlds, as the historian Edhem Eldem has defined him, ${ }^{42}$ but above all he was a man of his time. Hamdi was not an extraordinary man, and not even a kind of genius as he is often defined, worshipped by Turks and non-Turks or portrayed in the cafés of Istanbul. He was subject, like everybody, to the social structures that encompassed him and that he inevitably internalized. When he lived in Paris he integrated into the Parisian life. When he was forced back home in 1869, he absorbed the Ottoman culture and was influenced by Ottomanism. Lastly, because of his high social capital, and thus high social status, Hamdi began a career as a bureaucrat. That is how he became the director of the Imperial Museum. His values and beliefs, his expectations, his political ideology, his art, and as I have pointed out, his museum, were the expressions of his experiences of two worlds granted to him by familial wealth. Both Europe and the Ottoman milieu were filtered through his habitus and gave birth to something original. This is perhaps what made Hamdi the icon we all know. He was neither European nor was he Ottoman; he was both one and the other, and yet none of them. Overall and most importantly he was a product of his time, and so was his museum.

Citation: Lorenzo Posocco. "Osman Hamdi Bey and the Dawn of the Ottoman Museum: a Bourdieusian Approach" International Journal of Humanities Social Sciences and Education (IJHSSE), vol 8, no. 10, 2021, pp. 29-41. doi: https://doi.org/10.20431/2349-0381.0810005.

Copyright: (C) 2021 Authors. This is an open-access article distributed under the terms of the Creative Commons Attribution License, which permits unrestricted use, distribution, and reproduction in any medium, provided the original author and source are credited. 